\author{
А. С. Козлов
}

\author{
Aleksandr S. Kozlov \\ Ural Federal University \\ Ekaterinburg, Russia
}

\title{
ON TENDENTIOUS RECORDS IN THE CONTINUATIO PROSPERI HAUNIENSIS
}

This research reveals the features of ideological, political, and partly social orientation of the anonymous compilations formed in Italy (most likely shortly after $636 \mathrm{AD}$ ) and known as Continuatio Prosperi Hauniensis, which were the mixture of a chronicle, a duplicate of excerpts from numerous consular lists of the Roman Empire, and a brief overview of the rule of the Ostrogothic and Lombard kings. The author's attention is focused on the composition of the part of the "Continuation of Prosper" beginning with the events of the mid-fifth century. It is shown that the records saved all the features of a late antique chronicle, though the content uncovers obvious signs of imperfection and confused and incomplete editing (especially in the sections describing the disappearance of the imperial power in the West). On the contrary, the notes on the Lombard Period are clear and consistent in conceptuality. The data in this section of the records are definitely compiled by a single author who worked in the seventh century, most likely in Pavia (the main residence of the Lombard kings), and sought to reflect in his work the need to reconcile contemporary Italian elite with the leaders of barbarian conquerors. According to this anonymous compiler, the stability of the situation in Italy no longer depended on the empire, but rather on the barbarian rulers, who were mostly skilled and pragmatic warriors and politicians. In contrast to a number of sixth and seventh century chroniclers and historians, the compiler does not share the views of Gregory of Tours, Isidore of Seville, and John of Biclar, who advocated the use of force as the main means to achieve stability. He was closer to the "pacification" policy personified by Pope Gregory the Great.

Keywords: source studies of the Late Antiquity; Late Antique chronicles; Prosper of Aquitaine; Continuatio Prosperi Hauniensis

For citation: Kozlov, A. S. (2021). O tendentsioznosti zapisei v Continuatio Prosperi Hauniensis [On Tendentious Records in the Continuatio Prosperi Hauniensis]. Antichnaya drevnost' $i$ srednie veka, 49, 19-37. https://doi.org/10.15826/ adsv.2021.49.002

Submitted: 06.06.2021

Accepted: 11.10.2021 


\section{О тенденциозности записей в Continuatio Prosperi Hauniensis}

Хроникальные, в основном компилятивные записи, содержащиеся в Копенгагенском манускрипте № 454 Королевской библиотеки Дании (датируемом обычно XII в.) ${ }^{1}$, Т. Моммзен, включивший их в свой знаменитый компендиум Consularia Italica, назвал Continuatio Prosperi Hauniensis ${ }^{2}$. Название это, кроме всего прочего, в определенной степени отражает сложность и запутанность указанных записей как компиляции ${ }^{3}$ (см. об этом ниже). Актуальность данного документа прежде всего в том, что он фиксирует рефлексию части италийской знати VII в. на два крупных явления: исчезновение императорской власти на Западе в 470-е гг. и приспособление этой знати к завоеванию значительной части Италии лангобардами ${ }^{4}$. Однако понимание этой рефлексии, а значит, и специфики использования компилятором (или компиляторами?) своих источников, как правило, до сих пор ставит под сомнение стремление завершителя свода такого рода записей (назовем его, вслед за Моммзеном, Продолжателем) создать из их материала определенную цельность, дабы скомпоновать полноценную хронику знаковых событий V-VII вв. На вопрос о какой-то другой цели компилятора, о наличии у него какого-то исторического видения специалисты, как правило, отвечали отрицательно.

Превалировало мнение первого издателя и комментатора документа, Г. Хилле, заявлявшего: «Не может ускользнуть от чьего-либо внимания то, что вещи, почерпнутые у Иеронима, Проспера и Исидора, не имеют никакой пользы, кроме как для правки их же сообщений, ибо ломбардские дела лучше и точнее описаны Павлом Дьяконом, а немногое сообщаемое о папах и императорах едва ли обладает каким-то серьезным весом, - так что единственное, что достойно более тщательного

\footnotetext{
1 Лучшее описание манускрипта см.: Mommsen Th. Consularia Italica // MGH, AA. Berolini, 1882. T. IX. Vol. 1. P. 266-267; Muhlberger S. Heroic Kings and Unruly Generals: The "Copenhagen" Continuation of Prosper Reconsidered // Florilegium. 1984. T. 6. P. 67-70.

${ }^{2}$ Continuatio Prosperi Hauniensis / rec. Th. Mommsen // MGH, AA. Berolini, 1882. T. IX. Vol. 1. P. 298-305, 307-309, 311, 313, 317, 319, 321, 331, 333, 337-339 (далее в качестве ссылок на источник используются сокращения, принятые для обозначения его разделов в соответствии с их названиями, данными Т. Моммзеном).

${ }^{3}$ Речь, разумеется, идет прежде всего о компиляции знаменитой «Хроники» Проспера Аквитанского (ум. 460 г.). В статье используется классическое издание труда Проспера: Prosperi Tironis Epitoma Chronicon / ed. Th. Mommsen // MGH, AA. Berolini, 1892. T. XI. Vol. I. P. 385-499 (далее - Prosper). О запутанности, композиционном несовершенстве и незавершенности редакторской работы над той частью документа, которая касается фиксации событий до 523 г., см.: Козлов A. C. Особенности состава записей в Continuatio Prosperi Hauniensis // АДСВ. 2020. Т. 48. C.24-38.

${ }^{4} \mathrm{C}$ м. об этом: Holder-Egger O. Untersuchungen über einige analistische Quellen zur Geschichte des fünften und sechsten Jahrhunderts, II // Neues Archiv der Gesellschaft für ältere deutsche Geschichte. 1876. Bd. 1. S. 213-368; Mommsen Th. Consularia Italica. P. 266-267; Cessi R. Studi sulle fonti dell'età Gotica e Longobarda. II: Prosperi Continuatio Hauniensis // Archivio Muratoriano. 1922. T. 22. P. 585-641; Wes M. A. Das Ende des Kaisertums im Westen des römischen Reichs. 's-Gravenhage, 1967. S. 57-63; Muhlberger S. Heroic Kings... P. 50-70.
} 


\section{А. С. Козлов}

рассмотрения, это то, что вытекает из данных Равеннского Анонима (т. е. Комментатора, о котором ниже. $-A$. $K$.) $\rangle^{5}$. Не удивительно, что, начиная с Г. Хилле, все работы с текстом Продолжателя сосредоточивались на реконструкции материалов, связанных с $\mathrm{V}$ в., и освобождением их от более поздних наслоений. При этом сам последний компоновщик документа (он же его последний редактор, он же Продолжатель), живший в VII в., подвергался резкой критике. Даже Р. Чесси, сделавший наиболее заметный вклад в анализ Копенгагенского документа, оценил Продолжателя и его вклад в историографию раннесредневекового Запада весьма негативно и назвал его человеком, неспособным к оригинальности, часто омрачающим свои источники скверной риторикой или фантастическими толкованиями, проистекающими из вопиющего невежества в истории ${ }^{6}$.

Можно понять ригоризм исследователей, ищущих в Копенгагенском своде хоть какие-то литературные достоинства или реалии, обогащающие наши знания об Италии V - начала VII в. Ибо Продолжатель, работая в VII в., оказался, как выразился С. Малбергер, «непреодолимым барьером» между этими исследователями и использованными им оригинальными источниками ${ }^{7},-$ в то время как недостатки его собственного оригинального труда весьма очевидны. Его проза рутинна и претенциозна, а его знание истории, как верно заметил Р. Чесси, весьма ограничено. Лишь С. Малбергер, сосредоточив внимание на специфике эвристики, применяемой Продолжателем к своим источникам (в том числе к его примечательным компилятивным приемам), сумел выявить в финальном разделе Continuatio стремление идейно-политически оправдать аккомодацию части италийского общества к последствиям лангобардского господства ${ }^{8}$.

Мне кажется, что наблюдения С. Малбергера можно существенно скорректировать, расширить, показать, что тенденциозность последнего компилятора записей (так называемого Продолжателя) намного сложнее и более явная, чем полагали и полагают многие. Но для этого надо учитывать не только текст записей, касающихся событий VIVII вB., но и характер Копенгагенского документа в целом и, прежде всего, его композиции.

Она распадается на три объемных раздела, из которых легко идентифицируются первые два. Первый раздел, самый объемный, включает пассажи «Хроники» Иеронима, содержащей сообщения до 378 г;; откло-

\footnotetext{
${ }^{5}$ Hille G. Continuator Prosperi anni 641 ex Codice Hauniensi // Prosperi Aqvitani Chronici continuator havniensis / ed. G. Hille. Berolini, 1866. P. 12.

${ }^{6}$ Cessi R. Studi sulle fonti... P. 624-625.

${ }^{7}$ Muhlberger S. Heroic Kings... P. 55-56.

${ }^{8}$ Ibid. P. $62-63$.
} 


\section{О тенденциозности записей в Continuatio Prosperi Hauniensis}

нения от текста оригинала «Хроники» здесь невелики: есть несколько добавлений, взятых «из труда Исидора», из более развернутой версии «Хроники Проспера» и из трактата De viris illustribus самого Иеронима. Второй раздел базируется на тексте продолжения Проспером (до 455 г.) «Хроники» Иеронима. В издании Моммзена эта часть носит название Additamenta ad Prosperum Hauniensia (далее - AdPH). Следует подчеркнуть, что кодекс содержит текст сочинения Проспера Аквитанского в полном виде, а его хронология приводимых консулатов подменяет хронологию Иеронима, основанную на царствованиях. В то же время составитель VII в. существенно дополнил работу Проспера, включив в нее две записи Исидора, а также выписки из многих утраченных (преимущественно летописных) сочинений $\mathrm{V}$ в. В нескольких местах основного текста, на полях и даже в тексте менее исторически точной, но более литературной записи Проспера Копенгагенская компиляция добавляет точные даты и топонимы, заимствованные из одной или нескольких версий консулярий V в. Точно так же она включает в текст Проспера несколько более пространных эксцерптов из какого-то более подробного источника.

Здесь следует оговориться, что составитель (или составители) записей Копенгагенского манускрипта, как и многие другие скрипторы своего времени, разумеется, обращался с исходным материалом в соответствии с конкретными целями. В частности, у него имелись четкие взгляды на упадок Рима и складывание новых государств в Италии, взгляды, не лишенные значимости. В то же время эти записи отличает крайняя запутанность. Сам кодекс, созданный в XII или XIII вв., был небрежно скопирован со сложного и неполного протографа, отчего некоторые пассажи были опущены, а некоторые искажены. Ошибки создателя протографа исправлялись либо им самим, либо современниками как в самом тексте, так и добавлениями в виде маргиналий на полях. В результате записи под 458-474 гг. отсутствуют, а события 475-489 гг. дважды (хотя и несколько по-разному) презентуются в основном тексте и один раз в редакции маргиналий. структуру и ряд признаков более поздних интерполяций, текст документа наглядно демонстрирует представления его последнего по времени автора, работавшего в VII в., о фиксируемых событиях.

Еще раз следует обратить внимание на сложность самой компиляции, так же как и кодекса, ее содержащего. Ибо самым интересным и самым сложным разделом компиляции является третий. За своеобразие презентации исторических сведений Т. Моммзен охарактеризовал его автора как «уникального Копенгагенского Продолжателя Проспе-

\footnotetext{
${ }_{9}^{9}$ Учитывая текстологические особенности трех групп такого рода маргиналий, Т. Моммзен назвал их Auctarii Huniensis Ordo prior, Auctarii Huniensis Ordo priorposterior и Auctarii Huniensis Ordinis posterioris margo (далее соответственно - AHOpr, AHOpost, AHOpm).
} 


\section{А. С. Козлов}

pa» ${ }^{10}$. Первая часть этого раздела, названная Т. Моммзеном Auctarii Prosperum Hauniensis (далее - AРН) и охватившая период 455-523 гг., была создана уже в VII в. на базе разных источников, из которых известны лишь некоторые. Из «Хроники» Исидора Севильского, которая сама была сочинением VII в., был взят список императоров, правивших со времен Проспера по время составителя, плюс записи, касающиеся истории готов, империи и церкви. К хронологии понтификатов пап, презентуемой Проспером, здесь был добавлен материал неизвестного, но весьма точного списка понтификатов ${ }^{11}$. Однако основными источниками летописи, по крайней мере для фиксации событий до 523 г., были тексты, использовавшие данные консульских фаст, по-видимому, те же, что были взяты для Additamenta к Просперу. Они дали возможность автору (авторам) VII в. не только презентовать списки консулатов и совершавшихся при них событий (главный метод идентификации происходящего в те годы), но и добавить чисто исторические пассажи, включая его (их) собственное повествование о событиях времен лангобардов и Равеннского экзархата. Это повествование составило вторую часть раздела, которую Т. Моммзен назвал Auctarii Hauniensis (далее - АН). Природа этих источников, ранее уже отметившихся во втором разделе Копенгагенских записей, здесь выступает более рельефно. Некоторые из кратких, шаблонных, точно датированных пассажей характерны для консульских анналов, и очевидно, что здесь компилятор имел в своем распоряжении одну или несколько версий консулярий.

Другой источник записей данного раздела, хотя и базирующийся на пассажах хроник, гораздо интереснее. Это безапелляционная, хорошо оперирующая фактами история событий в Италии в V в., включая поражение Одоакра ${ }^{12}$. Работа этого комментатора событий V в. (в дальнейшем будем называть его Комментатором) является той частью «Продолжения», которая заслужила наибольшее внимание исследователей ${ }^{13}$. Характер компиляции здесь меняется еще раз, так как переписчик опускает списки консулов. Что касается труда так называемого Комментатора, то с констатацией поражения Одоакра в 493 г. сей труд либо

\footnotetext{
${ }^{10}$ Mommsen Th. Consularia Italica. P. 267.

11 Мною использован содержащийся в Копенгагенском кодексе Laterculus pontificum romanorum ex Codice Hauniensis (далее - LPRCH), см.: Mommsen Th. Consularia Italica. Р. 270-271.

${ }^{12}$ Комментарий относительно содержания данного источника см.: Wes M. A. Das Ende des Kaisertums... S. 66. Anm. 2.

${ }^{13}$ Everett $N$. Literacy in Lombard Italy, ca 568-774. Cambridge, 2003. (Cambridge Studies in Medieval Life and Thought. Fourth Series 4 ; Vol. 53). P. 86-87; Lo Monaco F. Dai Fasti a Fredegario // I Longobardi e la storia: Un percorso attraverso le fonti / ed. F. Lo Monasco, F. Mores. Rome, 2012. (Altomedioevo, 7). P. 75-104; Borri F. Romans Growing Beards: Identity and Historiography in Seventh Century Italy // Viator. 2014. Vol. 45, No 1. P. 45-49.
} 


\section{О тенденциозности записей в Continuatio Prosperi Hauniensis}

завершился, либо перестал интересовать компилятора. Консульский список, использованный Продолжателем, заканчивался на 523 г. Без этих двух документов сообщения Продолжателя как о хронологии событий, так и о самих событиях демонстрируют скудость и неточности. Хотя компиляция и продолжала презентовать списки императоров и пап, но уже не была способна привязать события к конкретным датам. Здесь компилятор, очевидно, работал с весьма ограниченным числом источников (узнаваем лишь краткий текст Исидора) и опирался на собственную память. Иначе говоря, у него было мало материала для фиксации событий периода от смерти Теодориха Великого до кампаний византийского полководца Нарсеса. Однако с констатации вторжения лангобардов записи становятся более полными, пока не завершаются описанием восшествия на престол и десятилетнего правления короля Адалоальда (616-625). Все эти особенности данной части записей, по форме разительно отличающейся от предыдущих частей, побудили в свое время Т. Моммзена назвать пассажи, фиксирующие события после 523 г., Auctarii Hauniensis Extrema (далее - АНЕ).

Следует учесть, что записи, содержащиеся в Копенгагенском манускрипте, естественно, легче всего описывать в рамках той терминологии, которую компиляция заимствовала у своих источников. Однако в этих пассажах есть и намеки на субъектность составителя. Он, несомненно, был италийцем и лучше всего знал историю Северной Италии и историю лангобардов ${ }^{14}$. Его отличающиеся деталями сведения о Павии и особый интерес к Лигурии, где располагался этот город, побудили Р. Чесси предположить, что Продолжатель Проспера был как-то связан с Павией, являвшейся в начале VII в. одним из основных центров королевства лангобардов ${ }^{15}$.

По поводу датировки окончательного оформления записей специалистами было предложено две версии. Многие приняли в качестве даты 641 г., так как пассаж, фиксирующий воцарение императора Ираклия (610-641), соотносится с тридцатым годом его правления. Т. Моммзен, однако, убедительно доказывал, что это замечание является интерполяцией и составление записей завершилось около 625 г. Списки пап и лангобардских королей завершаются в «Продолжении» примерно в том же году, и последующие события, происходившие либо в Италии, либо где-то еще, в «Продолжении» не отражены ${ }^{16}$.

${ }^{14}$ Borri F. Romans Growing Beards... P. 46-47.

15 О. Хольдер-Эггер (Holder-Egger O. Untersuchungen... S. 266. Anm. 2) и Р. Чесси (Cessi R. Studi sulle fonti... P. 625. № 2) независимо друг от друга предполагали, что Продолжатель происходил из Милана, хотя Чесси оговорился о предпочтительности Павии как места работы хрониста. Аргументация, приведенная ими на этот счет, представляется весьма нестрогой.

${ }^{16}$ Mommsen Th. Consularia Italica. P. 267. Cp.: Muhlberger S. Heroic Kings... P. 62. 


\section{А. С. Козлов}

Можно привести еще один аргумент в пользу более ранней даты, нежели 641 г., поскольку в некоторых важных моментах восприятие Продолжателем недавнего прошлого, по-видимому, отражает начало царствования Ираклия, а не его конец ${ }^{17}$.

Специально стоит отметить, что интерес Продолжателя к борьбе ортодоксии с иноверием, особенно с арианством, а также круг и содержание его образованности позволяют предполагать, что он был священнослужителем. Несмотря на незнание многих конкретных событий, он был хорошо знаком с христианской летописной традицией и явно стремился писать в ее рамках. Подобно Иерониму, Просперу и Исидору, он поместил историю своего времени в христианский контекст: недавняя история была частью истории спасения, последним звеном в цепи событий, восходящих к временам апостолов и патриархов, к самому Творению ${ }^{18}$.

Наконец, Продолжатель был автором с некоторыми литературными и историческими амбициями. Там, где в его тексте труд Иеронима смыкался с сочинением Проспера, и там, где текст Проспера переходил в текст самого Продолжателя, т. е. в тех местах, где хронисты традиционно могли заявить о своем творчестве, компилятор претендует на собственный вклад в «предание». В сочинении Проспера по подобному поводу (возможно, анонимным переписчиком) отмечалось: «До сих пор Иероним упорядочивал предшествующие годы; теперь к тому, что следует, было добавлено как описание последующих [за этими годами. $-A$. K.] дел весьма религиозным и ученым Проспером, были приложены кое-какие дополнительные замечания, результат нашего собственного изыскания (studiura)» ${ }^{19}$. В заключительной части «Продолжения» отмечено: «До сих пор святой Проспер продолжал историю, хотя мы и связали с ней некоторые вещи, которые он упустил, благодаря нашему изысканию в прошлых веках: то, что следует как наши собственные изыскания, насколько было возможно, было проделано с большим трудом» ${ }^{20}$. Продолжатель открыто признает свою зависимость от авторитетов прошлого, но в то же время презентует себя как скромного и одновременно слегка хвастливого их последователя, как этакого добросовестного школьника, скомпоновавшего более полную историю из доступного ему материала.

\footnotetext{
${ }^{17}$ Cp.: Mommsen Th. Consularia Italica. P. 267.

18 О роли хрониста как вдумчивого конструктора формы повествования в середине V в. рассуждал Идасий: Hydatii Lemici Continuatio chronicorum Hieronymorum ad a. CCCCLXVIII preface / ed. Th. Mommsen // MGH, AA. Berolini, 1894. T. XI. Vol. 2. P. 13-14.

${ }^{19}$ Цит. по: Mommsen Th. Consularia Italica. Р. 266.

${ }^{20}$ Ibid.
} 


\section{О тенденциозности записей в Continuatio Prosperi Hauniensis}

Конечно, в компиляции немало примеров использования одного источника для дополнения другого. Но в ней налицо и попытки (пусть слабые) придать написанному хотя бы видимость литературной целостности. Наиболее очевидным свидетельством в данном случае является использование в заключительной части «Продолжения» словесных реминисценций и топосов, взятых из использованных источников. Примечательным примером является дескрипция homo instructus bellicis rebus («человек, хорошо обученный военному делу»). Этот предикат высказан в отношении Одоакра и, по-видимому, как таковой в первый раз возник в тексте второго раздела «Продолжения». В следующей части Копенгагенских записей эта формулировка и близкие к ней вариации повторяются для характеристики нескольких других видных военных (AHOpr. a. 476.2; AHOpost. а. 476.2; е AHOpm. а. 476) ${ }^{21}$. Другой топос был заимствован у Проспера, который, говоря о семидесятидневной узурпации власти Петронем Максимом, подчеркнул ее вопиющую незаконность словами: sed temerae usurpationis audacia non diu potitus est («но в дерзости своей он не мог долго проявлять подобную несдержанность») 22 . Автору VII в. эта формулировка настолько понравилась, что он еще раз использовал ее для характеристики узурпации власти Элевтерием, экзархом Равенны, провозгласившим себя императором в 619 г. «Продолжение» подытоживает деяние экзарха словами sed temerae usurpationis audacia non diu potitus est («но в дерзости своей он недолго удерживал эту узурпированную власть») $)^{23}$. Но еще более показательно суждение документа о лангобардской угрозе Риму во времена папы Григория Великого. Согласно нашему автору, король Агилульф подошел к Риму со всеми своими силами для осады города, но повернул назад, когда папа встретил его на ступенях собора Св. Петра, смягчил его своими молитвами и глубоко взволновал своей мудростью и святостью (АНЕ. 17).

Никакой другой документ не упоминает об этом событии, и достоверность рассказа резонно ставится под сомнение; однако эта запись прекрасная демонстрация того, как автор следовал своим источникам при создании собственного повествования. Образцом для него в дан-

\footnotetext{
${ }^{21}$ Та же терминология используется для характеристики Велисария (AdPH. 28; cp.: Mommsen Th. Consularia Italica. Р. 309) и лангобардского герцога Сундрария (AНЕ. 22); аналогичные качества приписаны Пиерию, комиту Одоакра (АН. а. 491.1: qui bellicis rebus praeerat) и Теодориху (АН. а. 490: expertus bellicis rebus).

22 Prosper. 1375; cр.: АНЕ. 23. В связи с этим обращают на себя внимание замечания автора VII в. о королеве Розамунде, которая, убив своего мужа, не смогла сделать своего любовника королем, а затем бежала с ним в Равенну (АНЕ. 5: «но недолго они там оставались в живых, обходясь без воинской защиты»).

${ }^{23}$ AHE. 17. Cp.: Martindale J. R. The Prosopography of the Later Roman Empire. Cambridge, 1992. Vol. III: AD 527-641. P. 435-436.
} 


\section{А. С. Козлов}

ном случае был Проспер, чьи самые драматические эксцерпты демонстрируют, как папа Лев Великий лично спас Рим от Аттилы и смягчил разорение города Гейзериком (Prosper. 1367, 1375).

Пробелы в знании Продолжателем исторической конкретики, близкие к только что отмеченной аберрации италийской действительности $\mathrm{V}$ в., проявляются в изображении реалий близкого к нему VI в. Например, он сообщает, что когда готы были изгнаны из Италии Нарсесом, то они захватили Испанию, а Тотилу, последнего короля остготов, сменил вестгот Левигильд (АНЕ. 33$)^{24}$. Еще более поразительно его неведение относительно хода готских войн. Он знает, что отвоевание Апеннинского полуострова Нарсесом было вторым из двух крупных походов византийцев против готов, но он почти ничего не знает о первом походе кроме того, что он был вначале успешен, но кончился провалом. Продолжатель знал о Велисарии только благодаря Исидору, который описывал полководца лишь как победителя персов и вандалов, а потому, наверное, и не было оснований связывать Велисария с готской войной. Видимо, поэтому деяния Велисария в Италии оказались в Continuatio приписаны военачальнику Асбаду, известному нам по нескольким пассажам Прокопия, а Продолжателю - по эпитафии Асбаду в церкви Св. Назария в Павии. Надпись эта, полностью цитируемая Продолжателем, приписывала Асбаду изгнание gentes и передачу «Готских Альп под руку Лациуму». Видимо, она была для Продолжателя единственным источником информации о первых десятилетиях готских войн и, естественно, представляла ему весьма искаженную картину событий первой трети VI в. (AHE. 1-3)

Однако если в историографии Continuatio, начиная с Г. Хилле, источникам и ошибкам Продолжателя уделялось-таки внимание, то, как правило, не делалось акцента на том, что он - один из немногих свидетелей происходившего в Италии в VII в. Как-никак, но он был по меркам того времени образованным человеком и начитан лучше иных хронистов. Потому и следует взглянуть на то, как он обрабатывал и толковал исторические данные, которые компилировал.

\footnotetext{
${ }^{24}$ Моммзен считает это огрехом более позднего компилятора, но такой вывод вряд ли корректен. Эта ошибка не более вопиюща, чем приписывание хронистом VII в. деяний Велисария Асбаду. См.: Cessi R. Studi sulle fonti... Р. 622; Muhlberger S. Heroic Kings... P. 59.

${ }^{25}$ Cp.: Cessi R. Studi sulle fonti... P. 610-611. Прокопий сообщает, что Асбад, гепид на римской службе, в разное время был телохранителем Юстиниана, командиром гарнизона во Фракии и одним из подчиненных Нарсеса во время его успешной кампании против Тотилы. Асбаду приписывают нанесение смертельной раны Тотиле. См.: Martindale J. R. The Prosopography... Р. 133. Об идентификации Асбада и подобных ему военнослужащих как органичной части имперского общества V-VI вв. см.: Amory P. People and Identity in Ostrogothic Italy, 489-554. Cambridge, 2009. P. 190-192, 288, 319.
} 


\section{О тенденциозности записей в Continuatio Prosperi Hauniensis}

Здесь прежде всего бросается в глаза то, что Continuatio компоновалось как нечто большее, нежели нейтральная фиксация фактов. Примечательно уже то, что Продолжатель, обращаясь к теме поражений империи начала этого столетия, ориентирован на самую важную летопись Проспера и на труд Комментатора V в. Как известно, Аквитанец считал главной причиной бед империи гражданские войны и интриги, затеянные неуправляемыми военачальниками. Личные амбиции подорвали военную мощь Рима, а ранее компетентные полководцы либо уже плохо верили в свой долг, либо развратились ${ }^{26}$. Анонимный комментатор V в., видимо, придерживался схожего взгляда на события после исчезновения императорской власти на Западе: варвары захватили Италию благодаря внутренним разногласиям римлян. Тщеславие Непота и честолюбие Ореста открыли путь к власти Одоакру и Теодориху, которые, в отличие от римских предшественников, были умелыми военачальниками ${ }^{27}$. Компилятор VII в. принял эту концепцию и положил в основу своего взгляда на римскую историю.

Историю двух предыдущих столетий он описывал исключительно в рамках военной тематики и в военных терминах. Там, где опытные и энергичные полководцы, там всегда победа; правители и государства, лишенные воинских доблестей, обречены. Интересен в этом плане образ Одоакра, ибо он и победитель, и побежденный ${ }^{28}$. Впервые он зафиксирован в записи под 476 г. как лидер нелегитимного выступления герулов-федератов, охарактеризованных как лживые союзники. Однако критика не касается самого Одоакра, наоборот, он преподнесен как «человек, серьезный и по возрасту, и по благоразумию, и хорошо обученный военному делу». Имеет место неподчеркнутый текстом контраст между ним и римскими лидерами Непотом и Орестом, обладающими амбициями, но не имеющими способностей и рассудительности ${ }^{29}$. Одоакр быстро победил Ореста и ряд лет правил твердой рукой, подавляя внутренних соперников, завоевывал земли иноземных правителей, «расширяя свое господство битвой и мечом». Но Одоакр научился страху, когда Теодорих вступил в Италию, и таким образом утратил свою власть. Не одолев вторгшегося короля при Изонцо, Одоакр бежал и заперся со своим войском в Вероне. Компилятор дает понять, что это не было поступком истинного

\footnotetext{
${ }^{26}$ Prosper. 1278, 1286, 1294, 1310 (сообщения о папе Бонифации), 1335 (упоминание папы Литория), 1342 (сообщение о папе Себастьяне).

${ }^{27}$ AHOpr. a. 475.1; AHOpm. a. 475.1; AHOpm. a. 475, 2; a. 476, 1-2; AH. a. 490.

${ }^{28}$ Из последних работ по данному сюжету см.: Caliri E. Praecellentissimus Rex. Odoacre tra storia e storiografia. Messina, 2017. P. 151-160.

${ }^{29}$ AHOpr. a. 475.1; AHOpm. a. 475.1; AHOpm. a. 475, 2; a. 476, 1-2; AH. a. 490.
} 


\section{А. С. Козлов}

правителя. Зато Теодорих преподносится как «человек с духом, испытанным в воинском деле, и способный к триумфальной славе», который понимал, что нечего бояться врага, бежавшего после первого же поражения, и знал, что может победить, если будет преследовать соперника, надеявшегося больше на защиту стен, нежели на твердость своих людей (АН. а. 490). Хотя последующая запись показывает, что у Одоакра оставались еще душевные силы, но инициативу он так и не вернул. Причина этого - удача и мужество покидали его в решающие моменты, доверенные помощники погибли в сражениях, и сам он был вынужден заключить мир с Теодорихом, который при первой же возможности убил побежденного.

Примечательно, что никакой другой сюжет в документе не содержит подобных подробностей. Однако важность воинской доблести, а также позитив хорошей обученности военному делу подчеркиваются не раз. Велисарий, «человек, хорошо обученный в военном деле», как уже отмечалось, так подавил персов, «что одновременно вернул империю к ее изначальному состоянию и оставил врага в страхе». Затем «он также был послан в Африку и уничтожил вандалов вместе с их королем» (АdPH. Р. 269, по 28). Асбад и Нарсес играют аналогичную роль в Италии, только с большим эффектом: они не только рушат власть готов, но и восстанавливают в Италии гражданскую жизнь. Такими примерами автор VII в. явно подчеркивает, что безопасность и благополучие страны зависят от успеха компетентных полководцев; он также намекает, что такие люди в мирное время могут стать и лучшими правителями. Ведь «Асбад восстановил многие города Италии, и главным образом те, что в Лигурии»; затем цитируется упомянутая эпитафия Асбада, где говорится, что «благодаря тебе разные города с разрушенными стенами радуются возвращению своей первоначальной чести» (AНЕ. 1, 2). Смерть Асбада нарушила сей труд, но, к счастью, Нарсес оказался лидером схожего склада. Изгнав готов вторично и возвратив страну под руку империи, «он вернул людям всей Италии их изначальную отраду». В частности, он «восстановил города и стены в их первоначальном достоинстве и лелеял народ со справедливостью и благоразумием» $($ АНЕ. 3,4$)$. Очень важен тезис относительно того, что римляне давно не производили на свет таких лидеров.

Такого рода идейно-политический позитив явно контрастирует с последующим негативом, ибо козни положили конец благодетельному правлению Нарсеса и впустили в Италию лангобардов (АНЕ. 4), а чуть позже узурпация Фоки ослабила империю и открыла ее не только для последующих набегов лангобардов, но и для вторжений гуннов (имеются в виду авары) и персов. На глазах завершителя хроники римляне потеряли огромные территории и превратились в данников. Этот 


\section{О тенденциозности записей в Continuatio Prosperi Hauniensis}

тезис был позаимствован у Исидора ${ }^{30}$ точно так же, как понятие «муж, хорошо обученный воинскому делу» было взято у Комментатора. Однако данный тезис органично вписался в контекст сочинения и даже получил развитие. Логика безупречна: персы вырвали из-под римской власти и сделали своими данниками многие провинции; нападения аваров были отражены не сражениями, а золотом и дарами. Император Ираклий изображен стоящим под защитой стен и откупающимся от гуннов, угрожавших Константинополю. Его надежда на стены, а не на людей явно намекает на последние дни Одоакра (АНЕ. 10, 11, 13, 19, 20$)^{31}$.

Поражения Византии на Востоке явно повлияли на мировоззрение Продолжателя, но его, естественно, больше интересовали события в собственной стране. Ибо основной пример слабости римской власти взят им из италийской истории - рассказ о миссии Элевтерия, посланного императором Ираклием защитить византийские владения в Италии от лангобардов. Элевтерий потерпел поражение и был вынужден платить варварам трибут в обмен на мир. Умиротворив таким образом лангобардов, Элевтерий обратил свои полномочия во зло, провозгласил себя императором, но был убит солдатами (АНЕ. 21-23).

Подобная презентация материала - явное свидетельство того, что для автора VII в., обладателя узкого италийского кругозора, ослабление распадающейся империи - лишь последствие проявления обыденных пороков. В этом Продолжатель не одинок. Проспер Аквитанский также считал, что гражданские войны и интриги привели к падению Галлии, потере Карфагена и разграблению Рима вандалами. Еще более последовательно компилятор VII в. следует за суждениями Комментатора V в., утверждавшего, что распря 470-х гг. позволила герудам под руководством Одоакра создать королевство в Италии. Таким образом, составитель Копенгагенского документа полагал, что на его глазах повторяется одна и та же история. Со времен Нарсеса, но особенно начиная с мятежа Фоки, империя приходила в упадок. Главная причина этого

\footnotetext{
${ }^{30}$ Isidori Iunioris episcope Hispaliensis Chronica Maiora / ed. Th. Mommsen // MGH, AA. Berolini, 1896. T. XI. Vol. 2 (далее - Isidor). P. 478; АНЕ. 10, 13. По мнению С. Малбергера, тезис Т. Моммзена о том, что оба автора взяли эти пассажи из общего италийского источника, неубедителен. См.: Muhlberger S. Heroic Kings... P. 65. No 26.

31 Здесь стоит обратить внимание на способы, с помощью которых в документе подчеркивается совпадение внутренних и внешних невзгод, как это было в связи с событиями 476 г. (АНОрm. а. 476, 1: «В то время как опасные и неожиданные катастрофы постигают римских мужей внутри самого государства, против него восстают внешние народы, претендовавшие якобы на дружбу с римлянами»; ср. сообщение о восстании Фоки: АНЕ. 11: «Римляне, в то время как умножаются всяческие войны, в которых приходится серьезно сражаться, наносят ущерб государству, ибо в то время как внешний враг одолеть [их] не в состоянии, разжигают внутри себя пожар, способный развалить страну». См. также: АНЕ. 13: «В то время как это происходит внутри государства, вовне против него возбуждаются персы».
} 


\section{А. С. Козлов}

состояла в том, что римляне растратили военную мощь, которая у них оставалась, на борьбу друг с другом, в то время как их правители перестали опираться на доблестных солдат, а полагаться стали на подкуп своих врагов (АНЕ. 16, 22).

Очевидно, что Продолжатель считал возрождение Рима маловероятным. В обстановке многих поражений империи лангобардские короли и их военачальники (один из которых - противник Элевтерия) явно оказываются людьми, «хорошо обученными военному делу» и «одерживающими значительные победы» (AНЕ. 16,17$)^{32}$. Хронист не видит в этом ничего предосудительного: рассказывая (опираясь на память современников) о планировании римских городов при короле Агилульфе, он словно намекает на то, что города, управляемые лангобардами, безопаснее, нежели города византийской Италии. В связи с этим достойно внимания замечание о короле Аутари (584-590): «...благодаря своим способностям и благоразумию он восстановил силу лангобардов, которые были разбиты в Галлии, и победил франков, которые повсеместно опустошали Италию» (АНЕ. 8). Надо отметить, что какой-либо враждебности к присутствию лангобардов Continuatio не обнаруживает. Продолжатель упоминает «готскую свирепость» (не подтверждая ее фактами), но лангобардов не осуждает никогда, в отличие, например, от Григория Великого ${ }^{33}$, назвавшего их жестоким и отвратительным народом (АНЕ. 2) ${ }^{34}$. Даже Альбоина, возглавлявшего вторжение в Италию, документ аттестует как короля, правившего 33 года, в течение которых его народ после сражений в спокойной обстановке оседал в Италии (АНЕ. 5).

Намеренный контраст между воинственными и успешными лангобардами и разобщенными, деморализованными римлянами - актуальный прием Продолжателя. Такого рода подбор и подача материала показывает, что присутствие лангобардов на Апеннинах рассматривается в Continuatio не просто как важнейшее явление того времени. В самом деле, констатируя приход лангобардов, он удивительно мало пишет о византийской Италии, а когда сообщает о событиях на территории

32 Ср. сообщение о победах герцога Сундрария, «который устроил воинские дела при Агилульфе» (АНЕ. 22).

${ }^{33}$ Gregorii papae registrum epistolarum / ed. O. Ewald, L. M. Hartmann // MGH, Ep. Berolini, 1891. T. 1 (далее - Gregorius. Ep.).

34 Ibid. Ep. 5. 38 (сборщики налогов названы еще более жестокими, чем самые отвратительные лангобарды); cp.: Ibid. 7. 23. По поводу дискуссии об отношении Григория к негативным (на его взгляд) явлениям в италийском и имперском обществе, а также к лангобардам см.: Richards J. Consul of God: The Life and Times of Gregory the Great: The Life and Times of Gregory the Great. London, 1980. P. 81-94. Важно учесть, что хотя Григорий и не считал лангобардов безнадежным для христианского мира народом, он оценивал их как очень жестоких и вероломных людей. В Копенгагенском документе нет и намека на такие оценки. 


\section{О тенденциозности записей в Continuatio Prosperi Hauniensis}

экзархата или Пентаполя, то лишь в связи с каким-то лангобардским сюжетом. Например, если вернуться к пассажу об Элевтерии, то видно, что интерес автора к лангобардам явно повлиял на презентацию рассказа. Из Liber Pontificalis мы знаем, что не все современники считали Элевтерия неудачником. Согласно этому документу, главной заботой Элевтерия было восстановление законной власти на италийской территории Византии, и прежде чем возвратиться, он устранил убийц своего предшественника на этом посту и тирана, установившего контроль над Неаполем. И вообще Элевтерию приписывается восстановление мира во всей Италии ${ }^{35}$. Но для Continuatio все это не имеет значения; важно то, что Элевтерий не смог справиться с вызовом лангобардов изза своего неуместного честолюбия.

Церковные сюжеты в записях Продолжателя столь же избирательны. В частности, сравнение его текста с текстом Исидора Севильского обнаруживает некоторые поразительные упущения. Исидор много говорит о религиозных спорах VI в., и одним из его источников была хроника Виктора Туннунского, откровенного защитника решений Халкидонского собора от нападок императора Юстиниана ${ }^{36}$. Ни один из этих материалов не нашел места в Копенгагенском документе, хотя те проблемы, которые волновали Виктора, глубоко затронули и Италию. Ни единым словом Продолжатель не упоминает о церковных расколах, стимулированных Юстинианом, при котором Рим и ортодоксальные приходы были наособицу от католических кафедр Северной Италии, оказавшихся под лангобардами ${ }^{37}$. Желание Продолжателя избежать острых углов может объяснить такого рода лакуну в сочинении. Но все-таки умалчивание подобных фактов хорошо вписывается в осознанную лапидарность сообщений о византийской Италии.

Другое дело - проблема арианства, имевшая принципиальное значение для лангобардов и их италийских подданных. Продолжатель не упускает возможности разоблачить ложь арианской церкви или порадоваться

\footnotetext{
${ }^{35}$ Libri Pontificalis. Pars I / ed. Th. Mommsen // MGH, Gesta pontificum Romanorum. Berolini, 1898. Vol. 1. Р. 166, 168. Весьма примечательна полная независимость Liber Pontificalis и Continuatio друг от друга даже в вопросах хронологии понтификатов.

${ }^{36}$ См. презентацию Исидором церковных споров V-VI вв.: Isidor. 357, 381, 384, 385, 386a, 389a, 389b, 394a, 397a, 397b.

37 Этот раскол, как известно, был результатом спора о Трех Главах и продлился до конца VII в. Кроме всего прочего он осложнил усилия Григория Великого по обращению лангобардов в католичество, поскольку некоторые видные лангобардские католики, вроде королевы Теуделинды, привечали советников из числа такого рода схизматиков. Об этом споре см.: Amann E. Trois-Chapitres // Dictionnaire de théologie catholique. Paris, 1950. T. 15. Pt. 2. Col. 1868-1924. Если Продолжатель действительно был подданным Лангобардского королевства, то раскол, возможно, повлиял на его взгляды на империю, см.: Goffart W. Rome, Constantinople, and the Barbarians // American Historical Review. 1981. Vol. 86, No 2. P. 300-301.
} 


\section{А. С. Козлов}

ее поражению в Африке и Испании. Однако когда речь заходит об арианской вере лангобардов, тактика автора меняется. Он даже не намекает на ее существование. Более того, он восхваляет благочестие королевы Теуделинды, баварской принцессы, выходившей замуж за двух ломбардских королей, родившей третьего и являвшейся самой влиятельной католичкой в королевстве ${ }^{38}$. Молчание летописца о спорах, разделявших римских священнослужителей, и отсутствие акцента на том, что разделяло «варваров» и католиков в королевстве лангобардов, поразительны, но согласуются с характером презентации материала в других местах сочинения.

При всей своей римской учености и явной привязанности к римской церкви (особенно когда он восхваляет Григория Великого как человека невероятной духовной силы ${ }^{39}$ ) Продолжатель относится к империи почти равнодушно. Действительно, скорее всего он полагал, что Римская держава пережила свое время и что появление лангобардов было сигналом какого-то иного будущего. Недаром в значительном пассаже он называл византийскую Италию «той частью Италии, которая еще не занята лангобардами» (AНЕ. 21). Как уже говорилось, завершение записей в Continuatio следует относить к 625 г., когда на востоке империю теснили персы, а ответные походы Ираклия, несмотря на первоначальную эффективность, вот-вот должны были кончиться крахом. Свидетельства истории, насколько они были доступны Продолжателю, и собственный опыт лишали его имперского оптимизма. Имперская политика в Италии, несмотря на стабильность Равеннского экзархата, должна была казаться вялой, но презрение Продолжателя, например, к уплате империей трибута кому-либо выглядит как ошибочная позиция, ибо такие выплаты часто гарантировали империи внешнеполитический успех.

Однако следует учитывать, что акцент Continuatio на силе лангобардов и на слабости империи тогда не был оригинален. На рубеже VI-VII вв. духовные интеллектуалы Запада уже не только примирились с варварскими правителями, но и стали ценить их как королей-воинов. И если более ранние поколения образованных священнослужителей, реагируя на беды V в., принижали ценность мирских побед и проповедовали смирение (с заключением мирных соглашений), то их преемники к VII в. уже практиковали новый вид уважения к воинским добродетелям и к варварам, воплощавшим эти качества ${ }^{40}$. Подобную

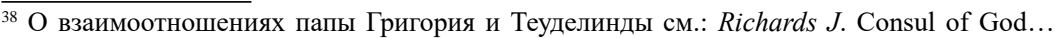
P. 181, 191-94.

${ }^{39}$ См.: LPRCH. P. 270 . No 55.

${ }^{40}$ Орозий, Проспер, Евгиппий и Эннодий Павийский являлись наиболее яркими авторами VI в., отвергавшими военные меры как способ решения проблем своего времени. Более «милитаристский настрой» можно увидеть у Григория Турского, Иоанна Бикларского и Исидора Севильского (Goffart W. Rome, Constantinople, and the Barbarians... P. 300-301).
} 


\section{О тенденциозности записей в Continuatio Prosperi Hauniensis}

переориентацию мы видим, например, в трудах Исидора Севильского. Как известно, Исидор оценивался тогда как ценитель и пропагандист классических наук, но он же в своих исторических трудах оправдывал готов как защитников Испании и положительно оценивал их усилия по изгнанию войск Византии из страны ${ }^{41}$. Составителю Continuatio до Исидора было далеко - и по мастерству, и по эрудиции. Однако во взглядах этих людей есть весьма сходные моменты, касающиеся причин процветания империи, даже когда победителями были варвары и еретики. Каждый в своем историческом труде вспоминал достижения римского прошлого, но был почти равнодушен (а то и враждебен) к империи VII в. Исидор был восторженнее в восхвалении готов, нежели италиец в описании лангобардов, но у Исидора было больше причин для удовлетворенности. При его жизни вестготы создали относительно единую, в общем католическую Испанию. Составитель Continuatio, возможно, мечтал о такой же судьбе для Италии ${ }^{42}$. Естественно, он не мог знать, что это будет не под силу лангобардам.

Таким образом, самое интересное в тексте Продолжателя - то, как он отражает трансформацию определенных срезов идеологии части верхушки италийского (и, вероятно, западноевропейского) общества первой четверти VII в. Еще исследования XIX в. показали стремительный рост медиевальности и соответствующей милитаризации как лангобардской, так и византийской Италии того времени. Специфика бесхитростного труда Продолжателя - сохранение основных черт тогдашнего мышления, когда позднеантичная гражданская знать Италии была окончательно подавлена и в значительной мере вытеснена новыми элитами $^{43}$. Образы, заполнившие его записи, оказываются воплощениями

${ }^{41}$ Наиболее четко это видно из контекста Historia Gothorum Исидора, но то же самое отношение просматривается и в последних частях его «Хроники», см.: Isidor. 403, 415, 416b.

42 Озабоченность Продолжателя благополучием Италии в целом отражается в его тексте повсюду, но особенно в первых пассажах Auctarii Hauniensis Extrema (AHE. 3-4). Неоднократное использование выражения totiusgue Italiae здесь особенно показательно. Tota Italia, omnis Italia и другие варианты подобного понятия явились топосами италийской политической мысли VI-IX вв., указывающими на континуитет осознания исторического единства страны и, возможно, стремления к его восстановлению. Интересно отметить, что текст Libri Pontificalis, как указывалось выше, в унисон с мыслями Продолжателя, оценивает победы Элевтерия над узурпаторами как «принесшие мир всей Италии» (Libri Pontificalis... P. 166). По этому вопросу см.: Classen P. Italien zwischen Byzanz und dem Frankenreich // Nascita dell'Europa ed Europa carolingia: un'equazione da verificare. Spoleto, 1981. (Settimane di Studi del Centro Italiano di Studi sull'Alto Medioevo ; 27). S. 920, 961-966. Ср.: «После него глубоко верующий король Свинтила начал войну против остальных римских городов и быстрой победой первым достиг единовластия над всем королевством Гиспании» (Isidor. 416b).

${ }^{43}$ Wickham Ch. Early Medieval Italy: Central Power and Local Society 400-1000. Ann Arbor, 1989. P. 71-72. 


\section{А. С. Козлов}

типов благоразумных, умелых воинов, олицетворяющих позитив того века, а также типов малодушных людей, побежденных и вытесненных ими. Но поскольку Продолжатель судил о прошлом по меркам своего времени, то история для него в основном состояла из эпизодов доблести и малодушия, побед и поражений. В этом отношении его можно считать в некоторой степени одним из предтеч тех, кто в Средневековье будет переосмысливать историю падения Рима в понятиях моралистической героики.

\section{REFERENCES}

Amann, E. (1950). Trois-Chapitres. In Dictionnaire de théologie catholique, 15(2) (pp. 1868-1924). Paris: Letouzey et Ané.

Amory, P. (2009). People and Identity in Ostrogothic Italy, 489-554. Cambridge: Cambridge University Press.

Borri, F. (2014). Romans Growing Beards: Identity and Historiography in Seventh Century Italy. Viator, 45(1), 39-71.

Caliri, E. (2017). Praecellentissimus Rex. Odoacre tra storia e storiografia. Messina: DICAM.

Cessi, R. (1922). Studi sulle fonti dell'età Gotica e Longobarda. II: Prosperi Continuatio Hauniensis. Archivio Muratoriano, 22, 585-641.

Classen, P. (1981). Italien zwischen Byzanz und dem Frankenreich. In Nascita dell'Europa ed Europa carolingia: un'equazione da verificare (pp. 919-967). Spoleto: Presso la sede del Centro.

Everett, N. (2003). Literacy in Lombard Italy, ca 568-774. Cambridge: Cambridge University Press.

Ewald, O., \& Hartmann, L. M. (1891). Gregorii papae registrum epistolarum. In Monumenta Germaniae Historica. Epistolae, 1. Berolini: Apud Weidmannos.

Goffart, W. (1981). Rome, Constantinople, and the Barbarians. American Historical Review, 86(2), 275-306.

Hille, G. (1866). Continuator Prosperi anni 641 ex Codice Hauniensi. In G. Hille (Ed.), Prosperi Aqvitani Chronici continuator havniensis (pp. 12-37). Berolini: Apud Weidmannos.

Holder-Egger, O. (1876). Untersuchungen über einige analistische Quellen zur Geschichte des fünften und sechsten Jahrhunderts, II. Neues Archiv der Gesellschaft für ältere deutsche Geschichte, 1, 213-368.

Kozlov, A. S. (2020). Osobennosti sostava zapisei v Continuatio Prosperi Hauniensis [Features of the Composition of Records in Continuatio Prosperi Hauniensis]. Antichnaya drevnost'i srednie veka, 48, 24-38.

Lo Monaco, F. (2012). Dai Fasti a Fredegario. In F. Lo Monasco, \& F. Mores (Eds.), Longobardi e la storia: Un percorso attraverso le fonti (pp. 75-104). Rome: Viella.

Martindale, J. R. (1992). The Prosopography of the Later Roman Empire (Vol. III: AD 527-641). Cambridge: Cambridge University Press.

Mommsen, Th. (Ed.). (1882a). Consularia Italica. In Monumenta Germaniae Historica. Auctores antiquissimi, 9(1), 249-339. 


\section{О тенденциозности записей в Continuatio Prosperi Hauniensis}

Mommsen, Th. (Ed.). (1882b). Continuatio Prosperi Hauniensis. In Monumenta Germaniae Historica. Auctores antiquissimi (T. 11, Vol. 1, pp. 298-339). Berolini: Apud Weidmannos.

Mommsen, Th. (Ed.). (1882c). Prosperi Tironis Epitoma Chronicon. In Monumenta Germaniae Historica. Auctores antiquissimi (T. 11, Vol. 1, pp. 385-499). Berolini: Apud Weidmannos.

Mommsen, Th. (Ed.). (1894a). Hydatii Lemici Continuatio chronicorum Hieronymorum ad a. CCCCLXVIII. In Monumenta Germaniae Historica. Auctores antiquissimi (T. 11, Vol. 2, pp. 1-36). Berolini: Apud Weidmannos.

Mommsen, Th. (Ed.). (1894b). Isidori Iunioris episcopi Hispaliensis Chronica Maiora. In Monumenta Germaniae Historica. Auctores antiquissimi (T. 11, vol. 2, pp. 391-488). Berolini: Apud Weidmannos.

Mommsen, Th. (Ed.). (1898). Libri Pontificalis. Pars I. In Monumenta Germaniae Historica. Gesta pontificum Romanorum (T. 1, pp. 1-454). Berolini: Apud Weidmannos.

Muhlberger, S. (1984). Heroic Kings and Unruly Generals: The "Copenhagen" Continuation of Prosper Reconsidered. Florilegium, 6, 50-70.

Richards, J. (1980). Consul of God: The Life and Times of Gregory the Great: The Life and Times of Gregory the Great. London: Routledge and Kegan Paul.

Wes, M. A. (1967). Das Ende des Kaisertums im Westen des römischen Reichs. 's-Gravenhage: Staatsdrukkerij.

Wickham, Ch. (1989). Early Medieval Italy: Central Power and Local Society 400-1000. Ann Arbor: University of Michigan Press.

\author{
Козлов Александр Сергеевич \\ кандидат исторических наук, доцент \\ кафедры истории Древнего мира \\ и Средних веков \\ Уральский федеральный университет \\ 620000, Екатеринбург, пр. Ленина, 51 \\ E-mail: alarich@yandex.ru
}

\author{
Kozlov, Aleksandr Sergeevich \\ $\mathrm{PhD}$ (History), Associate Professor \\ Ancient and Medieval History \\ Department \\ Ural Federal University \\ 51 Lenin Ave, 620000, Ekaterinburg, \\ Russia \\ Email: alarich@yandex.ru \\ https://orcid.org/0000-0002-9203-9169
}

